\title{
microRNA involvement in the onset and progression of Barrett's esophagus: a systematic review
}

\author{
Reilly J. Clark ${ }^{1, *}$, Michael P. Craig ${ }^{1, *}$, Sangeeta Agrawal ${ }^{2}$ and Madhavi Kadakia ${ }^{1}$ \\ ${ }^{1}$ Department of Biochemistry and Molecular Biology, Wright State University, Dayton, OH, USA \\ ${ }^{2}$ Dayton VA Medical Center, Dayton, OH, USA \\ *These authors have contributed equally to this work \\ Correspondence to: Madhavi Kadakia, email: madhavi.kadakia@wright.edu \\ Keywords: Barrett's esophagus; microRNA; EAC; biomarker \\ Received: October 27, $2016 \quad$ Accepted: December 22, $2017 \quad$ Published: January 11, 2018 \\ Copyright: Clark et al. This is an open-access article distributed under the terms of the Creative Commons Attribution License 3.0 \\ (CC BY 3.0), which permits unrestricted use, distribution, and reproduction in any medium, provided the original author and source \\ are credited.
}

\section{ABSTRACT}

Esophageal adenocarcinoma (EAC) is a highly aggressive malignancy that develops from Barrett's esophagus (BE), an intestinal metaplasia of the distal esophagus. microRNAs (miRNAs), short non-coding regulatory RNAs, are frequently dysregulated in BE and are thought to play key roles in the onset of BE and its progression to EAC. miRNAs thus have potential diagnostic and prognostic value and are increasingly being used as cancer biomarkers. This review summarizes the current literature related to miRNAs that are dysregulated in BE within the context of Hedgehog, Notch, MAPK, NF kappa-B, Wnt and epithelial-mesenchymal transition (EMT) signaling which are thought to drive BE onset and progression. This comprehensive analysis of miRNAs and their associated signaling in the regulation of BE provides an overview of vital discoveries in this field and highlights gaps in our understanding of BE pathophysiology that warrant further investigation.

\section{INTRODUCTION}

MicroRNAs (miRNAs) are evolutionarily conserved small non-coding RNAs of approximately 18-25 nucleotides in length which regulate gene expression by binding to the 3'-untranslated region (3'-UTR) of target mRNAs to inhibit their translation or facilitate their degradation [1]. miRNAs have been shown to regulate cell growth, differentiation and migration and are frequently dysregulated in cancer. Accordingly, there is considerable interest in identifying miRNA signatures characteristic of disease stage or therapeutic responsiveness. Further, microRNAs are being increasingly used clinically as cancer biomarkers because they frequently exhibit tissue-specific differences in expression, are stable in formalin-fixed tissues and blood and may be profiled without the need for an invasive muscle biopsy $[2,3]$. Serum miRNA biomarkers have particular appeal in diseases like Esophageal Adenocarcinoma (EAC) which are associated with extended monitoring periods, poor early detection, and costly or invasive methodologies.
Esophageal adenocarcinoma (EAC) is the dominant histologic type of esophageal cancer in Western society and its incidence is increasing. The precursor lesion for EAC, termed Barrett's esophagus (BE), is a metaplastic lesion of the distal esophagus in which the normal esophageal squamous epithelium is replaced by columnar epithelia and goblet cells. Patients with BE are 30-40 times more likely to develop EAC [4]. Gastroesophageal reflux disease (GERD) is the only known risk factor for $\mathrm{BE}$, and its prevalence is estimated to be as high as $30 \%$ in the United States [5]. Currently, white light endoscopy (WLE) with biopsy is the standard for diagnosis of BE and EAC [6]. The mortality rate in BE patients who develop EAC drops by $61 \%$ when patients are regularly monitored by WLE [7]. However, BE lesions that occur at the squamocolumnar junction or in the esophageal submucosal glands are not easily identifiable through WLE and thus not biopsied [8]. In addition, inflammation in the reflux-damaged epithelium can be misdiagnosed as dysplasia by WLE with biopsy [9]. Patient anxiety, adverse 
patient responses to sedatives, and high procedural costs also undermine the broad utility of this approach. Since the incidence of EAC in BE patients is only $0.55 \%$, the cost-effectiveness of surveillance monitoring by WLE and biopsy has also been questioned by recent meta-analyses $[7,10]$. It is therefore necessary to identify BE patients most at risk for $\mathrm{EAC}$, allowing $\mathrm{BE}$ patients with negligible risk to forego the cost, discomfort, and risks of repeated endoscopic procedures. Accordingly, there is a need for noninvasive serum biomarkers to identify the minority of patients at high risk for dysplasia who will benefit from surveillance.

$\mathrm{BE}$ and $\mathrm{EAC}$ research has identified a number of potential effectors of BE and EAC development which may have potential diagnostic or prognostic value. Proteins identified as differentially regulated in BE and EAC patients include Trefoil Factor 3, Anterior gradient 2, p16, villin, MUC2, and various columnar epithelial cytokeratins [11-15]. In addition, the differential expression of p63 in BE lesions has suggested a connection to normal mammalian embryonic development [16, 17]. However, none of these proteins or any combination thereof are in clinical use as biomarkers for BE or EAC. Fortunately, a number of miRNAs have been proposed as potential biomarkers for the diagnosis and monitoring of BE [1826]. Distinct miRNA signatures associated with GERD and BE were first described in 2008, and subsequent studies have expanded the list of miRNAs dysregulated in $\mathrm{BE}$ to at least 105 miRNAs potentially associated with $\mathrm{BE}$ pathophysiology [19, 20, 22-24, 27-32].

This review summarizes the current literature on miRNAs differentially expressed in BE within the context of the major signaling pathways they regulate as a means of highlighting the functional contribution of miRNAs to the onset and progression of BE. miRNAs shown to be dysregulated in $\mathrm{BE}$ relative to normal esophageal tissues are listed as upregulated or downregulated in Tables 1 and 2, respectively. Thirteen miRNAs have been identified from serum samples with the potential to serve as circulating biomarkers of BE. Twenty-four of the 105 miRNAs listed were identified as dysregulated in $\mathrm{BE}$ in more than one study and validated using multiple methodologies. Of the remaining 81 miRNAs, 53 were shown to be associated with BE in a single study only. Of note, miR-127-3p and miR-200a were reported as both upregulated and downregulated in $\mathrm{BE}$ and are thus listed in both Tables 1 and 2. The discrepancy may be due to differences in biopsy content (e.g. goblet cell levels), microenvironment (e.g. associated GERD) or lesion proximity to the squamocolumnar junction for the tissue samples evaluated in these studies. Additional testing is thus needed to clarify the role played by miR-127-3p and miR-200a in BE.

Validated human target genes for each of the BEassociated miRNA are also listed in Tables 1 and 2. The target genes listed were obtained from the Ingenuity
Pathway Analysis Knowledge Database (IPA®, QIAGEN Redwood City, www.qiagen.com/ingenuity), a curated database of findings from peer-reviewed scientific publications. The genes listed are high confidence interactions based on validation in human tumor cell lines. This list was chosen as a conservative list of functional targets for discussion herein, as it is impossible to discuss the full list of 10,512 predicted targets identified using Partek Genomics Suite (PGS, version 7.17, Target Scan 7.0 database query). In addition to the target genes listed in the IPA database, several additional targets have been included based on reports in the literature. These targets are underlined in Tables 1 and 2. Although the literature on signaling pathways in $\mathrm{BE}$ and $\mathrm{EAC}$ is extensive and spans over six decades, this review only focuses on miRNAs that are differentially regulated in $\mathrm{BE}$ and regulate Hedgehog, Notch, MAPK, NFкB, Wnt, and EMT signaling thought to underlie $\mathrm{BE}$ onset and progression.

\section{THE SQUAMOUS TO COLUMNAR TRANSITION OF BE: MIRNAS IN HEDGEHOG AND BMP SIGNALING}

$\mathrm{BE}$ is characterized by the conversion of normal squamous epithelium to an intestinalized columnar epithelium resembling an embryonic architecture. The molecular basis for this conversion is under debate, but it's believed to arise from a residual esophageal stem cell population as an adaptive response to chronic gastric reflux $[33,34]$. Hedgehog $(\mathrm{HH})$ signaling is thought to play a role because it is critical for regulating adult stem and progenitor cells during homeostasis and disease. HH signaling is absent in the normal adult esophagus but frequently upregulated in Barrett's epithelium, and $96 \%$ of EAC patients have elevated $\mathrm{HH}$ target gene expression $[35,36]$. HH signaling is stimulated by the ligands Desert/Indian/Sonic Hedgehog (D/I/SHH) binding the Patched-1 (PTCH1) receptor. Ligand binding to PTCH1 relieves inhibition of Smoothened (SMO), a G-protein coupled receptor-like protein, resulting in cleavage of the SHH repressor, Suppressor of Fused (SUFU) from the GLI transcription factors (Figure 1A). This cleavage allows the GLI proteins to initiate transcription of $\mathrm{HH}$ target genes [37].

miRNA regulation of $\mathrm{SHH}$ signaling in $\mathrm{BE}$ potentially occurs through miR-125b, which targets smoothened (SMO) and is downregulated in BE (Table $1)$, consistent with the expected increase in Hedgehogresponsiveness in BE [23]. Overexpression of miR$125 \mathrm{~b}$ has previously been observed in lung carcinoma cell lines, is associated with poor prognosis in HER2positive breast cancer patients and is dysregulated in neuronal progenitor tumor cells. Although these studies indicate miR-125b has oncogenic potential, its functional role in BE has not been investigated [38-40]. miR-194 targets SUFU and is upregulated in BE tissues [41]. 
Table 1: MicroRNAs downregulated in Barrett's esophagus

\begin{tabular}{|c|c|c|c|c|}
\hline MicroRNA & Source $^{a}$ & Validated human targets & Method of Detection ${ }^{c}$ & References \\
\hline $1-3 p$ & $\mathrm{P}$ & NCL, SERP1 & 9 & [27] \\
\hline $10 a-5 p$ & $\mathrm{P}$ & $\begin{array}{l}\text { HOXA1, HOXD10, KLF4, NF1, } \\
\text { USF2 }\end{array}$ & 3 & [27] \\
\hline $106 \mathrm{a}$ & $\mathrm{T}$ & $\begin{array}{l}\text { APP, ARID4B, HIPK3, MYLIP, } \\
\text { PAK7, RB1, RUNX1 }\end{array}$ & 3,6 & [29] \\
\hline $125 b$ & $\mathrm{~T}$ & $\begin{array}{l}\text { ADAMTS1, ALOX5, ANAPC16, } \\
\text { ATP6AP1L, B3GALT4, BAK1, } \\
\text { BMF, BMPR1B, CASP6, CASP7, } \\
\text { CBLN2, CBX7, CDC25A, CDK6, } \\
\text { CDKN2A, CEBPG, CYP1A1, } \\
\text { DICER1, DIO3, E2F3, ELAVL1, } \\
\text { SMO, ST18, ERBB2, ERBB3, } \\
\text { KRT19, FAM19A1, GPR160, } \\
\text { H3F3A/H3F3B, HIST1H4A, } \\
\text { ID1, ID2, ID3, IGFBP3, IL1RN, } \\
\text { JARID2, JUN, LIN28A MAN1A1, } \\
\text { PCDHB10, PERP, PIGR, RBM8A, } \\
\text { SGPL1, TENM2, TRNAK-UUU, } \\
\text { TSPAN8, UBE2I, UGT2B15, } \\
\text { UGT2B17, UGT2B28 }\end{array}$ & 10 & [30] \\
\hline $125 b-2-3 p$ & $\mathrm{~T}$ & -- & 1 & [23] \\
\hline $127-3 p$ & $\mathrm{P}$ & $\begin{array}{l}\text { BAG5, BCL6, COA1, GLE1, } \\
\text { PDIA6, PRDM1, } \underline{\text { SKI, XBP1 }}\end{array}$ & 9 & [27] \\
\hline $1260 \mathrm{~b}$ & $\mathrm{~T}$ & BCL6, PRDM1, XBP1 & 3,5 & [113] \\
\hline $133 a-3 p$ & $\mathrm{P}$ & $\begin{array}{c}\text { FSCN1, KLF15, KRT7, PKM, } \\
\text { RHOA }\end{array}$ & 9 & [27] \\
\hline $133 b$ & $\mathrm{~T} / \mathrm{P}$ & $\begin{array}{l}\text { KLF15, PKM, PITX3, PTBP2, } \\
\text { STK3 }\end{array}$ & 3,7 & [20] \\
\hline $136-5 p$ & $\mathrm{P}$ & -- & 9 & [27] \\
\hline 149 & $\mathrm{~T}$ & GIT1 & 4-Feb & {$[22,24,31]$} \\
\hline $149-5 p$ & $\mathrm{~T}$ & RAP1A, RAP1B, VAV2 & 3,5 & [113] \\
\hline $154-5 p$ & $\mathrm{P}$ & $\underline{\mathrm{E} 2 \mathrm{~F} 5}$ & 9 & [27] \\
\hline $18 a-3 p$ & $\mathrm{~T}$ & KRAS & 3,6 & [29] \\
\hline $193 b$ & $\mathrm{~T}$ & CCND1, ESR1, ETS1, PLAU & 3 & {$[22]$} \\
\hline $200 \mathrm{a}$ & $\mathrm{T}$ & $\begin{array}{c}\text { BAP1, CTBP2, CTNNB1 } \\
\text { (B-catenin), CYP1B1, ELMO2, } \\
\text { ERBB2IP, KLHL20, PTPRD, } \\
\text { TUBB, WDR37, ZEB1, ZEB2, } \\
\text { ZFPM2 }\end{array}$ & 3,7 & {$[20]$} \\
\hline 203 & $\mathrm{~T}$ & $\begin{array}{l}\frac{\text { ATM, BIRC5, BMI1, LIFR, }}{\text { RAB22A, RUNX2, SCOS1, SIK1, }} \\
\underline{\text { ZEB2 }}\end{array}$ & $2,3,6-8$ & $\begin{array}{c}{[18,20,23,24,29} \\
31,32,113]\end{array}$ \\
\hline \multirow[t]{2}{*}{205} & $\mathrm{~T}$ & $(-3 p)$ : none, $(-5 p)$ : see below & $1-4,6,7$ & $\begin{array}{c}{[18,23,24,29,31} \\
32]\end{array}$ \\
\hline & & & & (Continued) \\
\hline
\end{tabular}




\begin{tabular}{|c|c|c|c|c|}
\hline MicroRNA & Source $^{a}$ & Validated human targets $^{b}$ & Method of Detection ${ }^{c}$ & References \\
\hline $205-5 p$ & $\mathrm{~T}$ & $\begin{array}{c}\text { ERBB3, INPPL1, MED1, PRKCE, } \\
\text { VEGFA, ZEB1, ZEB2 }\end{array}$ & 3,5 & [113] \\
\hline $20 b$ & $\mathrm{~T}$ & $\begin{array}{c}\text { ARID4B, BAMBI, CRIM1, ESR1, } \\
\text { HIPK3, MYLIP, PPARG }\end{array}$ & 3,6 & [18] \\
\hline 210 & $\mathrm{~T}$ & FOXN3, SETD2 & 1,4 & {$[23,24]$} \\
\hline $224-5 p$ & $\mathrm{~T}$ & -- & 3,5 & [113] \\
\hline $23 b$ & $\mathrm{~T}$ & MET, PLAU & 1,4 & {$[23,24]$} \\
\hline $27 b$ & $\mathrm{~T}$ & $\begin{array}{l}\text { CYP1B1, MMP13, PPARG, ST14, } \\
\text { WEE1 }\end{array}$ & 3,4 & {$[22,24]$} \\
\hline $3065-5 p$ & $\mathrm{~T}$ & -- & 3,5 & [113] \\
\hline 31 & $\mathrm{~T}$ & $\underline{\text { DKK1, PRKCE, TIAM1 }}$ & 3,7 & [20] \\
\hline 32 & $\mathrm{~T}$ & BTG2, BCL2L11, MDM2, TSC1 & 3,6 & {$[18]$} \\
\hline $33 a-3 p$ & $\mathrm{~T}$ & $\underline{\mathrm{PBX} 3}$ & 1 & [23] \\
\hline 378 & $\mathrm{~T}$ & $\underline{\text { SUFU }}$ & 1,4 & {$[23,24]$} \\
\hline $378 \mathrm{c}$ & $\mathrm{T}$ & -- & 4 & [24] \\
\hline $382-5 p$ & $\mathrm{P}$ & $\underline{\text { MXD1 }}$ & 3 & [27] \\
\hline 4462 & $\mathrm{~T}$ & -- & 4 & [24] \\
\hline 543 & $\mathrm{~T}$ & NCL & 3,6 & [18] \\
\hline $708-5 p$ & $\mathrm{~T}$ & $\underline{\text { NNAT }}$ & 3,5 & [113] \\
\hline 744 & $\mathrm{~T}$ & $\frac{\text { BCL2, cMYC, GSK3ß, PDCD4, }}{\underline{\text { PTEN, PTP1B, SFRP1, TLE3 }}}$ & 4 & [24] \\
\hline 944 & $\mathrm{~T}$ & PTP4A1, SIAH1 & $1,2,3$ & {$[23,31,113]$} \\
\hline $99 a$ & $\mathrm{~T}$ & $\begin{array}{c}(-5 p): \text { FGFR3, IGF1R, MTOR, } \\
\text { RPTOR }\end{array}$ & 4 & [24] \\
\hline $99 a-3 p$ & $\mathrm{~T}$ & -- & 1 & [23] \\
\hline Let-7c & $\mathrm{T}$ & $\begin{array}{l}\text { ACVR1C, APC, APC2, BCL2L1, } \\
\text { BMPR1A, BTG2, EIF3J, HMGA2, } \\
\text { ITGB3, MED28, mir-30, MYC, } \\
\text { PBX2, PPP1R12B, RTCA, } \\
\text { SMAD2, SMAD4, STARD13, } \\
\text { TGFBR1, TRIB1, TRIM71 }\end{array}$ & $1,2,3,6$ & [23] \\
\hline
\end{tabular}

${ }^{a}$ Sample source: tissue (T) or plasma (P).

${ }^{\mathrm{b}}$ Validated human binding targets were obtained from Ingenuity Pathway Analysis Knowledge Database (IPA®, QIAGEN Redwood City, www.qiagen.com/ingenuity).

${ }^{c}$ Evidence (Table 1): 1: TaqMan Human miRNA Card Set v3.0, 2: Illumina microarray, 3: RT-PCR, 4: Affymetrix GeneChip miRNA 3.0 array, 5: SOLiD 3 sequencing, 6: OSU custom miRNA microarray chip (OSU_CCC version 4.0), 7: Agilent Human Microarray V2; 8: two-color competitive hybridization microarray, 9: mirVana miRNA Bioarrays (Ambion), 10: Exiqon Serum/Plasma Focus miRNA PCR panel.

Underlines indicate validated targets identified in published literature, but not yet listed in the IPA knowledge base.

The resulting loss of SUFU would lead to increased GLI transcriptional activity and HH target expression, as observed in BE. miR-378 is also known to target the SHH pathway through its targeting of SUFU, a negative regulator of SHH signaling, but its downregulation in
$\mathrm{BE}$ (Table 1) is inconsistent with the observed increase in SHH signaling [42]. miR-378 is reduced in EAC, suggesting that it may have diagnostic or prognostic value, but its role in $\mathrm{BE}$ physiology remains unclear $[23,24]$. 
Table 2: MicroRNAs upregulated in Barrett's esophagus

\begin{tabular}{|c|c|c|c|c|}
\hline MicroRNA & Source $^{a}$ & Validated human targets ${ }^{b}$ & $\begin{array}{l}\text { Method of } \\
\text { Detection }^{c}\end{array}$ & References \\
\hline $122-5 p$ & $\mathrm{P}$ & $\begin{array}{l}\text { AACS, ADAM17, AKT3, ALDOA, ANK2, } \\
\text { ANXA11, AP3M2, ATP11A, ATP1A2, } \\
\text { BACH2, BCL2L2, CCNG1, CLDN18, } \\
\text { CS, DSTYK, DUSP2, EGLN3, ENTPD4, } \\
\text { FAM117B, FOXJ3, FOXP1, FUNDC2, } \\
\text { G6PC3, GALNT10, GYS1, MAPK11, MECP2, } \\
\text { MEP1A, NCAM1, NFATC1, NFATC2IP, } \\
\text { NUMBL, OSMR, PALM, RAB11FIP1, } \\
\text { RAB6B, RABIF, SLC7A1, SLC7A11, TBX19, } \\
\text { TPD52L2, TRIB1, TTYH3, UBAP2, XPO6 }\end{array}$ & 9 & {$[27]$} \\
\hline $127-3 p$ & $\mathrm{~T}$ & $\underline{\mathrm{BAG} 5}, \mathrm{BCL} 6, \frac{\mathrm{COA} 1, \mathrm{GLE} 1, \mathrm{PDIA} 6, \mathrm{PRDM} 1,}{\underline{\text { SKI}}, \mathrm{XBP} 1}$ & 3 & [114] \\
\hline $130 \mathrm{~b}$ & $\mathrm{~T}$ & $\frac{\frac{\text { CYP2C9, CYLD, DICER1, FMR1, IGF- }}{1, \text { MMP2, NKD2, NRP1, PPAR } \gamma, \text { PTEN }}}{\underline{\text { RUNX3, STAT3 }}}$ & 2,3 & {$[31]$} \\
\hline $133 \mathrm{a}$ & $\mathrm{T}$ & FSCN1 & 1 & [23] \\
\hline $135 b-3 p$ & $\mathrm{~T}$ & -- & 3 & {$[114]$} \\
\hline $136-3 p$ & $\mathrm{~T}$ & $\underline{\text { ADAM9, LHR, SLC7A5 }}$ & 1 & {$[23,114]$} \\
\hline 143 & $\mathrm{~T}$ & $\begin{array}{c}\text { DNMT3A, FNDC3B, KRAS, MAPK7, PLK1, } \\
\text { PRC1, TOP2A }\end{array}$ & $1,3,8$ & {$[23,32]$} \\
\hline 145 & $\mathrm{~T}$ & FOXO1, FOXO3, MYC, SRF & $1,3,4,3$ & {$[23,24,113]$} \\
\hline $145-3 p$ & $\mathrm{~T}$ & MTDH, UHRF1 & 1 & {$[23]$} \\
\hline $146 \mathrm{a}$ & $\mathrm{T}$ & $\begin{array}{l}\text { ATOH8, BLMH, BRCA1, CCL8, CCNA2, } \\
\text { CDKN3, CFH, COL13A1, CXCR4, FADD, } \\
\text { KIF22, IRF5, LTB, MCM10, MCPH1, } \\
\text { METTL7A, MR1, NFIX, NUMB, PDIK1L, } \\
\text { PA2G4, PEX11G, PLEKHA4, PBLD, } \\
\text { POLE2, PRR15, RAD54L, SDCBP2, STAT1, } \\
\text { TIMELESS, TLR4, TMSB15A, TRIM14, } \\
\text { UHRF1, VWCE }\end{array}$ & 2,3 & {$[31]$} \\
\hline $148 \mathrm{a}$ & $\mathrm{T}$ & DNMT3B, DNMT1, NR1I2, RPS6KA5 & 1,4 & {$[23,24]$} \\
\hline $151-3 p$ & $\mathrm{~T}$ & ATP2a2, TWIST1 & 4 & {$[24]$} \\
\hline $151-5 p$ & $\mathrm{~T}$ & $\underline{\text { SMARCA5, TWIST1 }}$ & 4 & {$[24]$} \\
\hline 153 & $\mathrm{~T}$ & BCL2, FOXO1, MCL1 & 2,3 & {$[31]$} \\
\hline $15 \mathrm{a}$ & $\mathrm{T}$ & BCL2, CHEK1, WEE1 & 1 & [23] \\
\hline $181 \mathrm{a}$ & $\mathrm{T}$ & IRF8, MCL1, PBX3 & 4 & {$[24]$} \\
\hline $181 b$ & $\mathrm{~T}$ & $\begin{array}{l}\text { AICDA, BCL2, CDX2, CYLD, ESR1, GATA6, } \\
\text { GRIA2, NLK, PLAG1, TCL1A, VSNL1 }\end{array}$ & 4 & {$[24]$} \\
\hline $187-3 p$ & $\mathrm{~T}$ & -- & 3 & [113] \\
\hline 191 & $\mathrm{~T}$ & PTEN, ZEB2 & 4 & [24] \\
\hline 192 & $\mathrm{~T}$ & $(-3 p): \underline{S C D}, \mathrm{ALDH} 3 \mathrm{~A} 2$ & $2,3,4,6,7$ & {$[18-20,24,29,31]$} \\
\hline $192-5 p$ & $\mathrm{~T}$ & DHFR, DTL, TYMS & $2,3,5$ & {$[31,113]$} \\
\hline 194 & $\mathrm{~T}$ & $\underline{\text { SUFU }_{2}}(-3 p): \underline{\text { AP-1, FOSL1 }}$ & $2,3,4,7$ & {$[19,20,24,31]$} \\
\hline $194-5 p$ & $\mathrm{~S} / \mathrm{T}$ & $\underline{\mathrm{AKT} 2}$ & $2,3,5,9$ & {$[27,31,113]$} \\
\hline 195 & $\mathrm{~T}$ & DHFR, DTL, TYMS & 1,4 & {$[23,24]$} \\
\hline
\end{tabular}

(Continued) 


\begin{tabular}{|c|c|c|c|c|}
\hline MicroRNA & Source $^{a}$ & Validated human targets ${ }^{b}$ & $\begin{array}{l}\text { Method of } \\
\text { Detection }^{c}\end{array}$ & References \\
\hline 196a & $\mathrm{T}$ & (-3p): LSP1, NRP2, TYMS, ZG16 & $2,3,4$ & {$[24,31][19]$} \\
\hline $196 a-5 p$ & $\mathrm{~T}$ & $\begin{array}{l}\text { ANXA1, COL1A1, HOXA7, HOXB8, } \\
\text { HOXD8, HOXC8, IKBKB, KRT5, S100A9, } \\
\text { SPRR2C }\end{array}$ & 3,5 & [113] \\
\hline $196 b$ & $\mathrm{~T}$ & $\frac{\text { BCL2, cMYC, GATA6, HOXA9, IGF2BP1, }}{\text { TGFBR2 }}$ & $2,3,4$ & {$[31][24]$} \\
\hline 1974 & S & -- & 9 & [27] \\
\hline $199 a-5 p$ & $\mathrm{~T}$ & ALOX5AP & 1 & {$[23,114]$} \\
\hline 200a & $\mathrm{T}$ & $\begin{array}{l}\text { BAP1, CTBP2, CTNNB1, CYP1B1, ELMO2, } \\
\text { ERBB2IP, KLHL20, PTPRD, TUBB, WDR37, } \\
\text { ZEB1, ZEB2, ZFPM2 }\end{array}$ & 2,3 & {$[31]$} \\
\hline $200 \mathrm{~b}$ & $\mathrm{~T}$ & $\begin{array}{l}\text { BAP1, CTBP2, CTNNB1, CYP1B1, ELMO2, } \\
\text { ERBB2IP, KLHL20, PTPRD, TUBB, WDR37, } \\
\text { ZEB1, ZEB2, ZFPM2 }\end{array}$ & $2,3,4$ & {$[24,31]$} \\
\hline $200 \mathrm{c}$ & $\mathrm{T}$ & $\begin{array}{l}\text { ERRFI1, FHOD1, MARCKS, NOG, PLCG1, } \\
\text { PPM1F, PTPN13, ZEB1, JAG1 }\end{array}$ & 10 & {$[30]$} \\
\hline 21 & $\mathrm{~T}$ & $\begin{array}{l}\text { ACTA2, APAF1, BMPR2, BTG2, C8orf44- } \\
\text { SGK3/SGK3, CDC25A, CDK6, CDKN1A, } \\
\text { CFL2, CLU, FAM3C, FAS, FBXO11, GLCCI1, } \\
\text { HIPK3, IL6R, IRAK1, JAG1, LRRFIP1, } \\
\text { MARCKS, MTAP, MYD88, NFIB, PDCD4, } \\
\text { PDCD4, PIK3R1, PRRG4, PTEN, RECK, } \\
\text { RP2, SERPINB5, SESN1, SLC16A10, SOCS5, } \\
\text { SOD3, SOX5, TGFBR2, TIAM1, TIMP3, TNF, } \\
\text { TPM1 }\end{array}$ & $1,2,3,4$ & {$[19,22-24,31]$} \\
\hline 214 & $\mathrm{~T}$ & ING4, PTGS2 (COX2), PTEN & 4 & [24], -5p [114] \\
\hline 215 & $\mathrm{~T}$ & DHFR, DTL, TYMS & $1,2,3,6,8$ & {$[18,23,29,31,32]$} \\
\hline 223 & $\mathrm{~T}$ & $\begin{array}{l}\text { AR, CYB5A, FBXW7, GFPT1, HMGCS1, } \\
\text { IRS1, KIF1BP, LMO2, MT1E, NFIA, PARP1, } \\
\text { RHOB, SCARB1, SLC11A2, SLC39A1, } \\
\text { SMARCD1, SP3, STMN1, STMN1 }\end{array}$ & 1 & [23], -5p [114] \\
\hline $223-5 p$ & $\mathrm{~T}$ & $\underline{\text { IL-6, STAT-3, TP63 }}$ & 1 & [23] \\
\hline 25 & $\mathrm{~T}$ & MDM2, TSC1, ZNF512B & $1,3,4,5$ & {$[23,24,113]$} \\
\hline $26 a-1-3 p$ & $\mathrm{~T}$ & -- & 1 & [23] \\
\hline $28-5 p$ & $\mathrm{~T}$ & GPX2, IGF1, MAD2, RAP1B, SEPSH2 & 4 & [24] \\
\hline $29 \mathrm{c}$ & $\mathrm{T}$ & -- & 1 & [23] \\
\hline $29 c-3 p$ & $\mathrm{~T}$ & $\begin{array}{c}\text { CDC42, COL1A1, COL1A2, COL3A1, } \\
\text { COL4A1, COL4A2, COL15A1, DNMT3A, } \\
\text { DNMT3B, FBN1, LAMC1, PIK3R1, SPARC, } \\
\text { SRSF10, TDG }\end{array}$ & 1 & [23] \\
\hline $301 \mathrm{~b}$ & $\mathrm{~T}$ & $\underline{\text { BIM, NDRG2, TP63 }}$ & 1 & [23] \\
\hline $30 a-3 p$ & $\mathrm{~T}$ & $\begin{array}{l}\text { CDK6, CYR61, FMR1, SLC7A6, THBS1, } \\
\text { TMEM2, TUBA1A, VEZT, WDR82 }\end{array}$ & 1 & [23] \\
\hline $338-3 p$ & $\mathrm{~T}$ & UBE2Q1 & $1,3,5$ & {$[23,113]$} \\
\hline $3613-5 p$ & $\mathrm{~T}$ & -- & 2,3 & {$[31]$} \\
\hline 375 & $\mathrm{~T}$ & KIAA1524, YAP1, YWHAZ & 4 & [24] \\
\hline
\end{tabular}

(Continued) 


\begin{tabular}{|c|c|c|c|c|}
\hline MicroRNA & Source $^{a}$ & Validated human targets & $\begin{array}{l}\text { Method of } \\
\text { Detection }^{\mathrm{c}}\end{array}$ & References \\
\hline $376 c-3 p$ & $\mathrm{~T}$ & -- & 3 & [114] \\
\hline $409-3 p$ & $\mathrm{~T}$ & $\frac{\text { AKT1, ANG, Beclin-1, cMET, CTNND1, }}{\underline{\text { GAB1, PHF10, ZEB1 }}}$ & 1 & {$[23,114]$} \\
\hline $424-5 p$ & $\mathrm{~T}$ & $\begin{array}{l}\text { ANLN, ATF6, CCND1, CCNE1, CCNF, } \\
\text { CDC14A, CDC25A, CHEK1, FGF2, } \\
\text { FGFR1, KIF23, GALNT13, MAP2K1, mir-9, } \\
\text { MGAT4A, NFIA, OGT, PLAG1, SPI1, WEE1 }\end{array}$ & $1,2,3$ & {$[23,31,114]$} \\
\hline 4417 & $\mathrm{~T}$ & -- & 4 & {$[24]$} \\
\hline $450 b-5 p$ & $\mathrm{~T}$ & $\underline{\mathrm{MET}, \mathrm{SOX} 2}$ & 1 & {$[23]$} \\
\hline $451 \mathrm{a}$ & $\mathrm{S}$ & ABCB1, AKTIP, FBXO33, MIF & 9 & {$[27]$} \\
\hline $487 \mathrm{~b}$ & $\mathrm{~T}$ & CDKN2AIP, MAP2K4 & 3 & {$[22]$} \\
\hline 492 & $\mathrm{~T}$ & $\underline{\text { CD147, PTEN, RETN, SOX7 }}$ & 1 & {$[23]$} \\
\hline 497 & $\mathrm{~T}$ & $\frac{\text { BCL2, BDNF, E2F3, FRA1, HIF1a, HDGF, }}{\frac{\text { KCa3.1, mTOR, NRDP1, SIRT4, SLUG, }}{\underline{\text { SMAD7, VEGFA, VEGFR2, YAP1 }}}}$ & 1 & {$[23]$} \\
\hline $501-5 p$ & $\mathrm{~T}$ & CYCLD, DKK1, GSK3 $\beta$, NKD1 & 1 & {$[23]$} \\
\hline 503 & $\mathrm{~T}$ & $\begin{array}{l}\text { AGO1, ANLN, ATF6, CCND1, CCNE1, } \\
\text { CCNE2, CCNF, CDC14A, CDC25A, CDKN1A, } \\
\text { CHEK1, FGF2, FGFR1, mir-9, WEE1 }\end{array}$ & 4 & {$[24]$} \\
\hline $542-3 p$ & $\mathrm{~T}$ & ILK, PTGS2 (COX2) & 1 & {$[23]$} \\
\hline $548 b-3 p$ & $\mathrm{~T}$ & -- & 3,6 & {$[18]$} \\
\hline $551 b-3 p$ & $\mathrm{~T}$ & -- & 3,5 & [113] \\
\hline 618 & $\mathrm{~T}$ & $\underline{\text { XIAP }}$ & 1 & {$[23]$} \\
\hline 625 & $\mathrm{~T}$ & $(-3 p):$ MAP2K6, SCAI; $(-5 p):$ NTRK3 & 2,3 & {$[31]$} \\
\hline 642 & $\mathrm{~T}$ & -- & 1 & {$[23]$} \\
\hline 7 & $\mathrm{~T}$ & $\begin{array}{c}\text { EGFR, IRS1, IRS2, KMT5A, NEFM, PAK1, } \\
\text { RAF1, SLC3A2, SNCA }\end{array}$ & 2,3 & {$[31]$} \\
\hline $95-3 p$ & $\mathrm{~S}$ & $\underline{\text { CELF2, CCND1 }}$ & 9 & {$[27]$} \\
\hline Let-7 & $\mathrm{T}$ & MYC & 4 & {$[24]$} \\
\hline
\end{tabular}

${ }^{\text {a }}$ Sample source: tissue (T), plasma (P) or serum (S).

${ }^{\mathrm{b}}$ Validated human binding targets were obtained from Ingenuity Pathway Analysis Knowledge Database (IPA@, QIAGEN

Redwood City, www.qiagen.com/ingenuity).

${ }^{c}$ Evidence (Table 2): 1: TaqMan Human miRNA Card Set v3.0, 2: Illumina microarray, 3: RT-PCR, 4: Affymetrix GeneChip miRNA 3.0 array, 5: SOLiD 3 sequencing, 6: OSU custom miRNA microarray chip (OSU_CCC version 4.0), 7: Agilent Human Microarray V2, 8: two-color competitive hybridization microarray; 9: Exiqon Serum/Plasma Focus miRNA PCR panel, 10: mirVana miRNA Bioarrays (Ambion).

Underlines indicate validated targets identified in published literature, but not yet listed in the IPA knowledge base.

Ectopic HH signaling blocks the expression of Noggin, an inhibitor of the BMP (bone morphogenic protein) pathway, leading to increased BMP4 signaling and resulting in failed stratification of the columnar epithelium and a BE phenotype [43]. BMP signaling promotes expression of stem cell genes while suppressing genes involved in cell death. BMP signaling is increased in $\mathrm{BE}$ and is thought to function in the maintenance of epithelial stemness in BE [44]. BMP signaling occurs through the receptor-mediated SMADs (SMAD1/5/8) which associate with the co-mediator SMAD4 and are translocated to the nucleus to activate BMP target gene expression [45]. Increased bile acids associated with GERD and BE have been shown to directly stimulate $\mathrm{HH}$ signaling and increase expression of PTCH1 and BMP4 in the BE stroma [36]. Other downstream targets of elevated $\mathrm{HH}$ in $\mathrm{BE}$ include SOX9, a transcription factor important in intestinal crypt development, and FOXA2, a driver of 
the intestinal mucin MUC2 [46, 47]. Collectively, these studies suggest bile reflux elevates $\mathrm{HH}$ signaling which induces an intestinal phenotype through BMP4, SOX9 and FOXA2 in the esophageal squamous epithelium.

The elevated BMP signaling observed in BE is potentially mediated by miR-200c, miR-130 and let-7c (Figure 1B). miR-200c is upregulated in BE (Table 2) and directly targets and inhibits Noggin expression, and thus is a potential contributor to the enhanced BMP signaling observed in $\mathrm{BE}[30,48]$. Let- $7 \mathrm{c}$ is downregulated in $\mathrm{BE}$ and may contribute to increased BMP signaling by increasing both SMAD2 and SMAD4 levels [23, 49].

\section{THE SQUAMOUS TO COLUMNAR TRANSITION OF BE: MIRNAS AND NOTCH SIGNALING}

In the normal esophagus, Notch signaling is strongest in the basal layer of stratified epithelia, where it maintains normal differentiation and stratification [50]. Signaling is induced when Delta-like ligand 1/2 (DLL1/2) or Jagged1/2 (JAG1/2) interacts with the NOTCH1/2 receptor, resulting in cleavage of its intracellular domain (NICD) (Figure 2A). NICD combines with recombination signal binding protein for immunoglobulin kappa J region
(RBPJ) and Mastermind-like proteins (MAML), forming a transcriptional complex [51]. JAG1 is frequently downregulated in $\mathrm{BE}$ resulting in the loss of Notch signaling and epithelial stratification [52]. Interestingly, Notch signaling is elevated during the progression of $\mathrm{BE}$ to EAC suggesting that miRNA regulation of Notch signaling may be disease stage-dependent [53].

As shown in Table 2, miR-21, miR-200c, miR-122$5 \mathrm{p}$ and miR-146a are upregulated in BE and target the Notch pathway (Figure 2A) [24, 27, 30]. miR-21 and miR200 c target JAG1 resulting in loss of NOTCH activation, consistent with a role in mediating the squamous to columnar transition in $\mathrm{BE}[54,55]$. miR-122-5p is also upregulated in BE and targets the Notch agonist ADAM17, potentially reducing the ADAM17-mediated cleavage of NOTCH and downstream signaling [27, 56, 57]. MiR$146 \mathrm{a}$ is upregulated in $\mathrm{BE}$ and has been shown to target the Notch antagonist NUMB, raising the possibility that miR-146a is involved in re-establishing Notch signaling upon dysplastic progression of BE $[53,58]$. Finally, miR200a inhibits the C-terminal binding protein 2 (CTBP2) which serves as a co-repressor of RBPJ [59]. Loss of miR200a would lead to increased CTBP2 levels and could account for the inhibition of Notch signaling expression in $\mathrm{BE}$, but there are conflicting reports on how miR-200a expression is altered in $\mathrm{BE}$.

\section{(A) Hedgehog (elevated in BE)}

\section{(B) BMP (elevated in BE)}

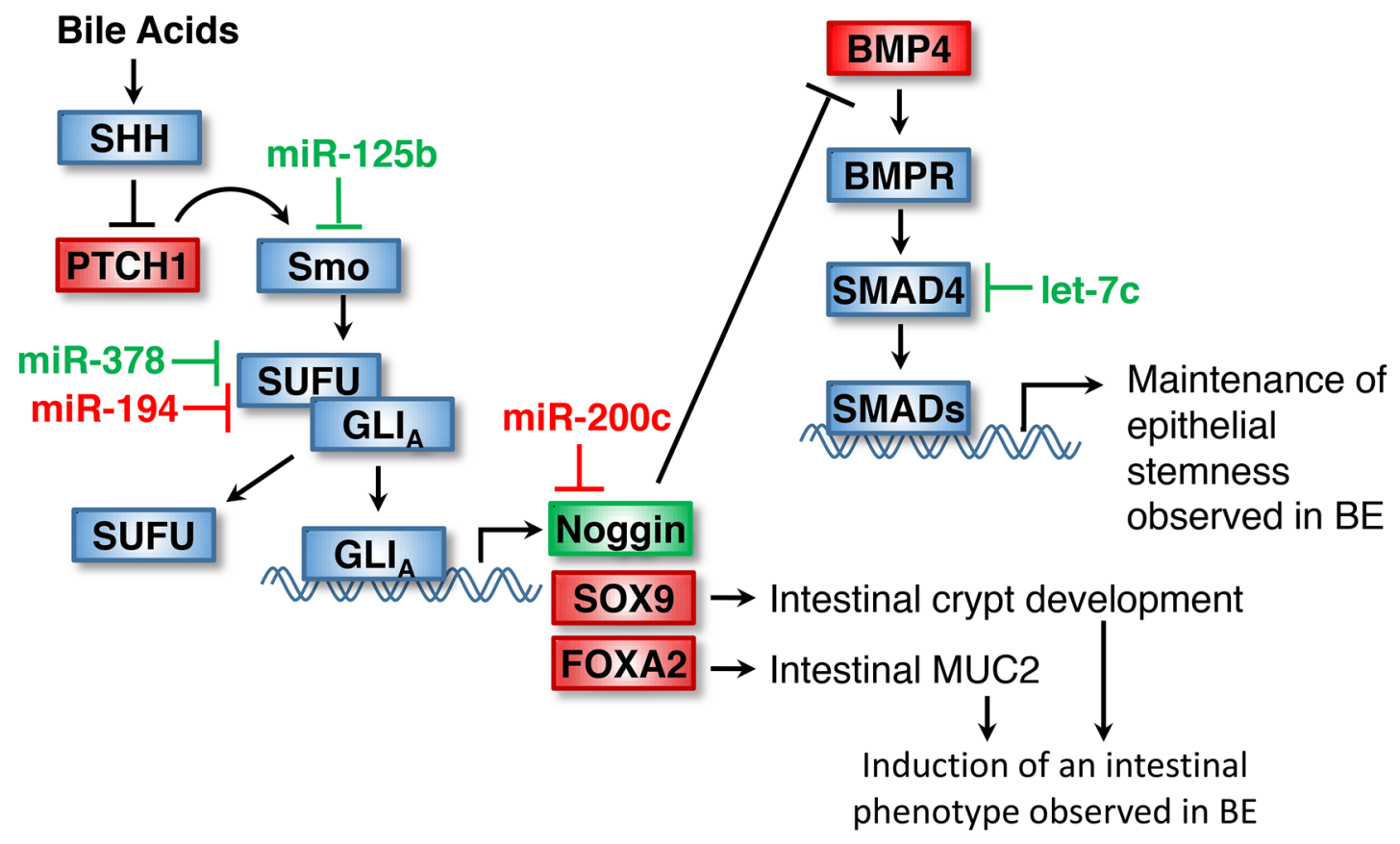

Figure 1: Maintenance of stemness in BE by Hedgehog and BMP signaling. (A) Upregulation of Hedgehog signaling in BE is thought to occur as an adaptive response to chronic bile acid exposure in GERD. Loss of miR-125b and increased expression of miR194 in BE would de-repress Smoothened and SUFU respectively and serve to facilitate SHH signaling. (B) Increased BMP signaling in $\mathrm{BE}$ is thought to result from a loss of the HH target Noggin, potentially a result of elevated miR-200c expression. Loss of Let-7c may also contribute to increased BMP signaling. Items shown in red and green are upregulated and downregulated in BE, respectively. 


\section{INTESTINALIZATION OF THE COLUMNAR EPITHELIUM: MIRNAS IN CDX2 AND MAPK SIGNALING}

The Caudal Type Homeobox 2 (CDX2) transcription factor drives the expression of intestinal genes and those involved in goblet cell differentiation and is upregulated in BE (Figure 2) [60]. Increased CDX2 levels in BE are promoted by reduced Notch signaling, unconjugated bile acids in GERD, activation of $\mathrm{p} 38$, and by the inactivation of ERK signaling [17, 61-63]. Although increased activation of the ERK Mitogen Associated Protein Kinase (MAPK) has been observed in GERD patients without $\mathrm{BE}$, reduced phosphorylation of the ERK is frequently observed in Barrett's epithelium relative to the normal squamous epithelium suggesting that ERK activation by gastric acid is abrogated in BE [61, 64, 65]. ERK inactivation in $\mathrm{BE}$ is thought to promote the observed increase in CDX2 transcriptional activity and promote the terminal differentiation of intestinal epithelial cells [66].
As shown in Table 2, several miRNAs upregulated in $\mathrm{BE}$ are predicted to target the ERK pathway (Figure 2B). ERK is activated by the binding of growth factors (EGF, FGF) to their receptors (EGFR, FGFR). EGFR is targeted by miR-7, while miR-424 and miR-503 target both FGF and the FGFR $[67,68]$. Reduced ERK activation occurring as a consequence of EGFR and FGFR inhibition by these miRNAs potentially explains the observed reduction in signaling through the RAF-RASMEK-ERK kinase cascade in BE [69]. Within the pathway itself, upregulation of miR-143 and miR-7 observed in BE may also contribute to the loss of ERK signaling through downregulation of KRAS and RAF1, respectively [70, 71].

Of note, increased MAPK signaling through JNK and p38 is believed to contribute to the intestinalization in $\mathrm{BE}$ through induction of activated AP-1, a transcription complex that includes JUN and FOS heterodimers [72]. $\mathrm{AP}-1$ is responsible for the expression of MUC5AC in BE lesions, as well as several genes involved in inflammation and carcinogenesis [73-75]. miR-21 is known to inhibit the TNF ligand and the TGF $\beta$ receptor, upstream activators

(A) NOTCH (lost in BE)

(B) MAPK (reduced ERK and increased p38 and JNK in BE

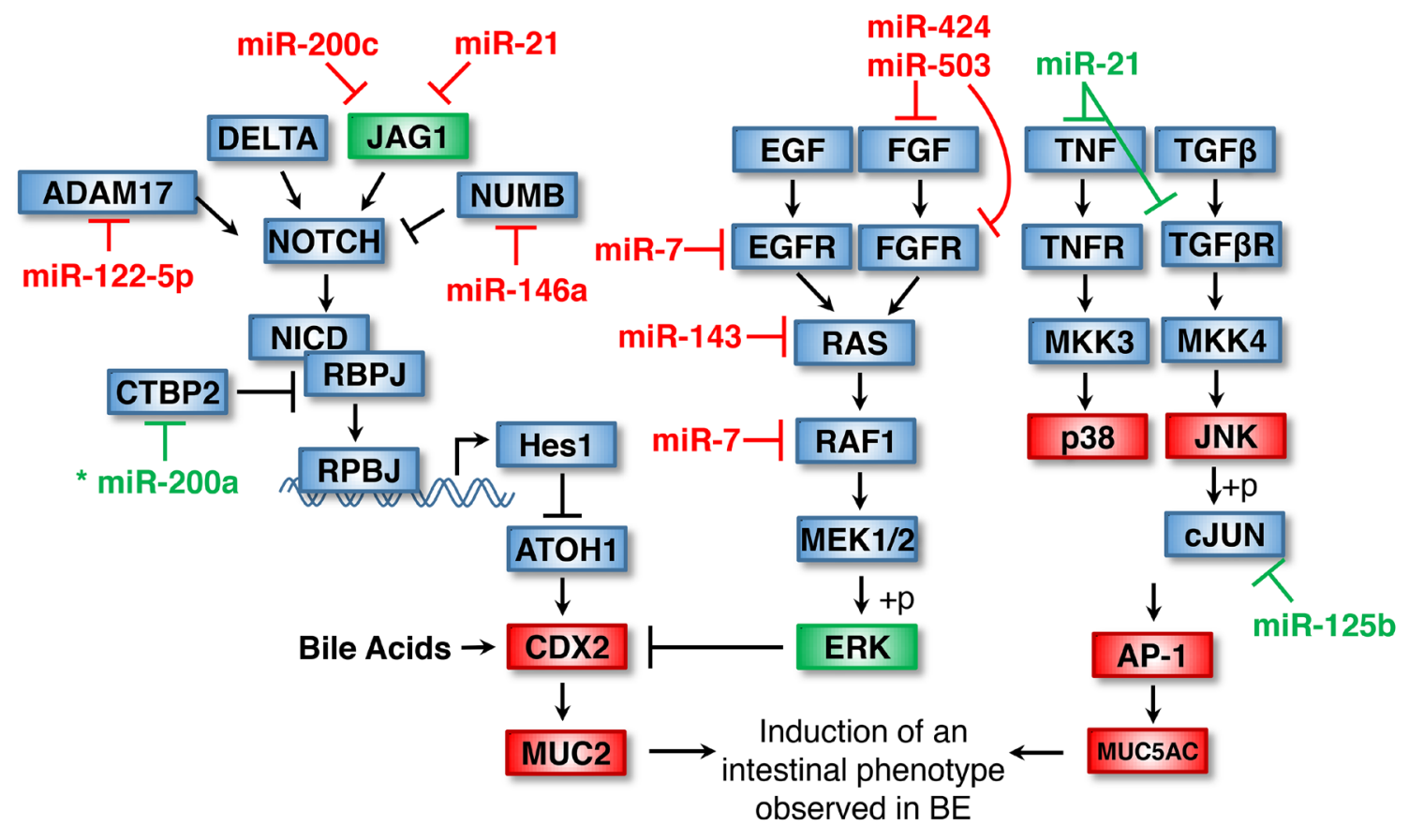

Figure 2: Loss of epithelial stratification and intestinalization of the columnar epithelium by Notch, CDX2 MAPK signaling. (A) Loss of NOTCH signaling in BE is thought to occur as a consequence of diminished JAG1 ligand expression which may result from an upregulation of miR-200c and miR-21 in BE. Enhanced miR-122-5p expression may abrogate NOTCH signaling through repression of the NOTCH agonist ADAM17. Loss of miR-200a potentially contributes to NOTCH suppression by alleviating repression of the co-repressor CTBP2 and leading to destruction of the NICD/RBPJ transcriptional complex. Loss of NOTCH signaling reduces HES1 expression, relieving ATOH1 inhibition and leading to increased CDX-2 and MUC2 levels observed in BE. (B) Loss of ERK signaling in BE may be explained by an upregulation of several BE-associated miRNA, including miR-424, miR-503, mir-7, miR-143 and miR-7. Loss of ERK has also been linked to increased CDX2 levels. Loss of miR-21 and miR-125b may contribute to increased p38 and JNK kinase levels observed in BE. Asterisk indicates miRNA with unclear regulation in BE. Items shown in red and green are upregulated and downregulated in BE, respectively. 
of p38 and JNK, respectively. miR-21 is downregulated in $\mathrm{BE}$, consistent with an increase in both signaling cascades and consistent with a role for miR-21 in BE (Table 1) [24]. miR-125b targets cJUN and is also downregulated in BE, thus potentially leading to an increase in other factors downstream of JNK (Table 1) [30, 76].

\section{DYSPLASTIC PROGRESSION TO EAC: MIRNAS IN WNT SIGNALING}

Wnt signaling is critical for normal intestinal development and homeostasis (Figure 3), and is thought to play a critical role in the dysplastic progression of $\mathrm{BE}$ to EAC [77]. Wnt signaling is normally active in the esophagus after its separation from the foregut, but is absent in BE due, in part, to an upregulation of the WNT inhibitor Dickkopf-related protein 1 (DKK1) [78, 79]. Increased DKK1 prevents recruitment of glycogen synthase kinase-3 $\beta$ (GSK3 $\beta$ ) and Adenomatosis Polyposis Coli (APC) to the cell membrane, thus facilitating $\beta$-catenin phosphorylation and degradation. The resulting loss of nuclear $\beta$-catenin reduces transcription of Wnt target genes as observed in BE [80]. By contrast, increased nuclear $\beta$-catenin is observed in high-grade dysplasia suggesting that canonical WNT/ $\beta$-catenin activation does not contribute to the onset of $\mathrm{BE}$ but instead promotes the dysplastic progression of BE to EAC [78, 81]. SOX17, a negative regulator of $\mathrm{WNT}$, is progressively lost in the progression from normal mucosa to EAC, but it remains unclear whether SOX17 directly contributes to the metastatic progression to EAC [82]. miR-141 has been shown to downregulate SOX17 expression in esophageal cancer cell lines, thus potentially activating Wnt signaling to promote esophageal tumorigenesis, but miR-141 dysregulation in BE or EAC has not yet been reported [82].

Loss of WNT activation in BE is potentially linked to a downregulation of miR-31, miR-744, let-7c and miR$200 \mathrm{a}$ in BE, although the contribution of these miRNAs to the progression to EAC remains unclear (Table 1). miR-31 directly targets the Wnt inhibitor DKK1, thus providing a possible explanation for the observed increase in DKK1 levels in BE $[20,83]$. The subsequent elevation of miR31 in EAC relative to BE suggests a potential role for miR-31 in the progression to EAC in a manner similar to its role in lung cancer where it is known to enhance proliferation and tumorigenicity through upregulation of Wnt signaling [20, 84]. miR-744 has also been shown to directly target several negative modulators of Wnt $/ \beta$-catenin signaling, including glycogen synthase kinase $3 \beta$ (GSK3 $\beta$ ) [15]. The observed loss of miR744 is thus consistent with diminished Wnt signaling in $\mathrm{BE}$, but unlike its role in driving WNT activation and tumorigenicity through increased expression in pancreatic

\section{WNT (lost in BE, elevated in EAC)}

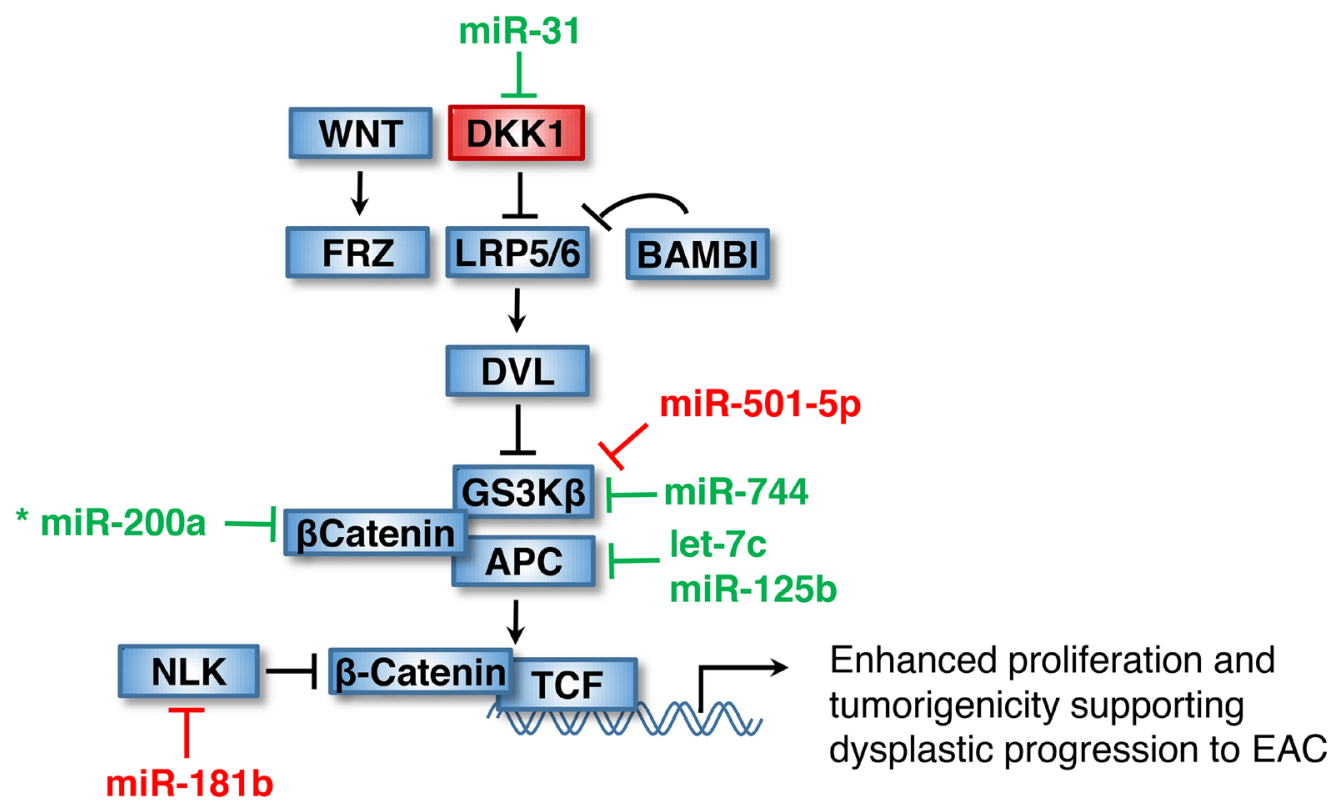

Figure 3: Dysplastic progression to EAC through WNT activation. WNT signaling is lost in BE but elevated during dysplastic progression to EAC. Loss of WNT signaling in BE is thought to occur as a consequence of elevated DKK1 levels, potentially resulting from miR-31 loss. Subsequently, loss of let-7c, miR-125b and miR-200a and increased miR-181b levels may contribute to WNT activation in EAC by facilitating accumulation of nuclear $\beta$-catenin and activation of WNT target genes. Asterisk indicates miRNA with unclear regulation in BE. Items shown in red and green are upregulated and downregulated in BE, respectively. 
cancer, miR-744 is instead reduced in EAC calling its role in dysplastic progression to EAC into question [85]. Loss of let-7c potentially leads to an increase in APC levels and stabilization of the destruction complex and may serve to limit $\beta$-catenin transactivation in $\mathrm{BE}[24,38,49]$. Like miR-744, Let-7c is subsequently reduced in EAC [21].

A number of BE-related miRNAs have targets in the Wnt signaling cascade and potentially play a role in promoting Wnt signaling during its metastatic progression toward EAC. Upregulation of miR-181b in BE decreases Nemo Like Kinase (NLK), alleviating repression of TCF and facilitating TCF/LEF binding to Wnt-response elements and increasing Wnt target gene expression (Table 2) $[24,86]$. Although a definitive link to BE or EAC has not been established, miR-181b, shown to increase tumor metastasis in a mouse model of non-small cell lung carcinoma (NSCLC), is upregulated in both metastatic human NSCLC and breast cancer and is regulated by CDX2 [87, 88]. miR-501-5p may similarly activate Wnt signaling by inhibiting GSK3 $\beta$, thus promoting malignant behavior in EAC as previously observed in gastric cancer [89]. Additionally, loss of miR-200a in meningiomas was shown to promote tumor growth by directly targeting betacatenin (CTNNB1), but its role in BE remains unclear due to conflicting reports on the dysregulation of miR-200a $[20,31,90]$.

\section{(A) NFKB (elevated in GERD, BE and EAC)}

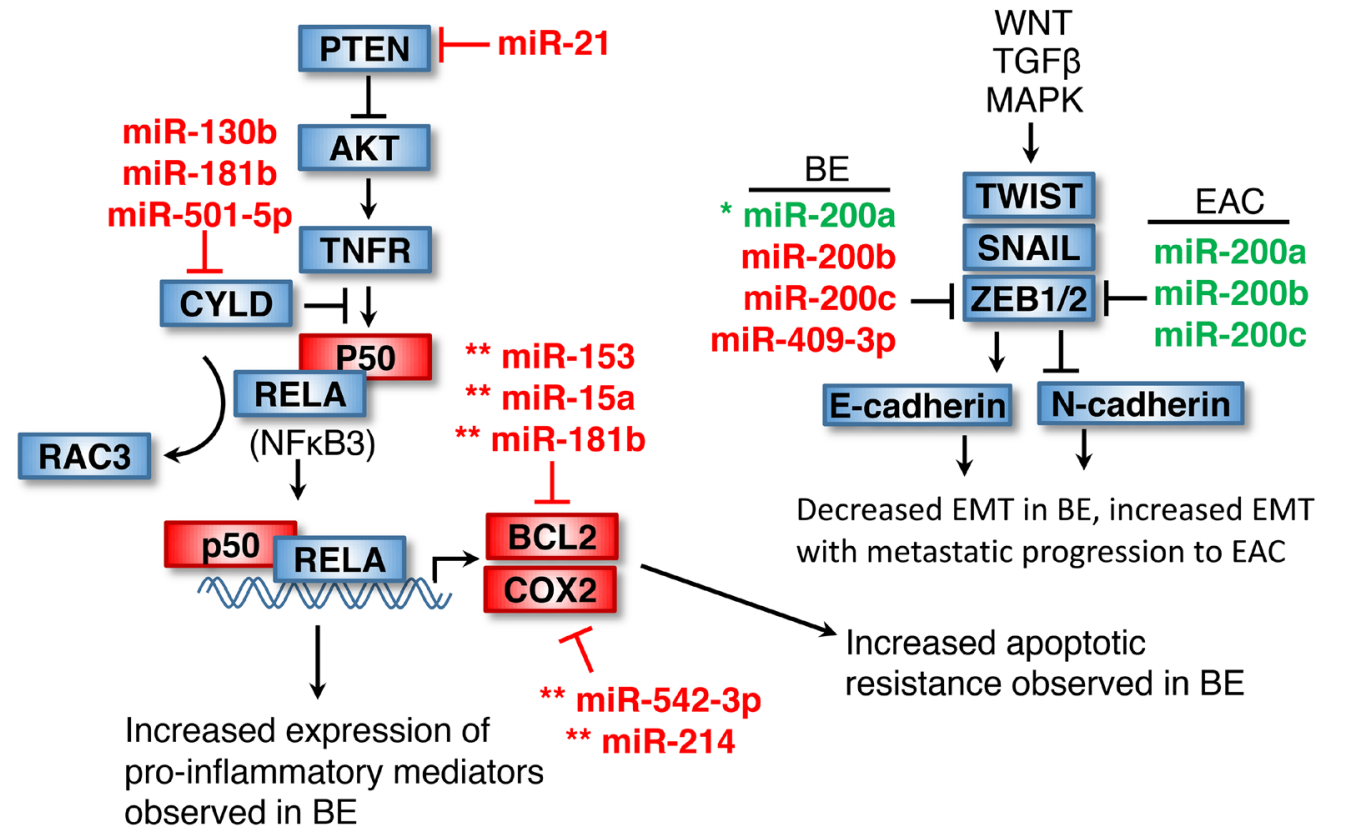

Figure 4: Elevated NF-кB signaling and EMT in EAC. (A) NF- $\mathrm{BB}$ signaling is elevated in GERD, BE and EAC, potentially due to increased miR-130b, miR-181b or miR-501-5p-mediated suppression of the NF- $\mathrm{BB}$ suppressor CYLD. BCL2 and COX2 are elevated in BE as a result in increased NF- $\mathrm{KB}$ signaling. The miRNA which target these mRNA (marked with an asterisk) are upregulated and inconsistent with a role in BE or EAC. (B) EMT is increased during the MDC progression to EAC. The miR-200 family of miRNA and miR-409-3p are increased in $\mathrm{BE}$ and thus potentially function to suppress ZEB1 and ZEB2 during early stages. miR-200 family miRNAs are subsequently suppressed in EAC, thus correlating with increased ZEB1 and ZEB2 and thus EMT. Asterisk indicates miRNA with unclear regulation in BE. Double asterisk indicates miRNA regulation inconsistent with a role in $\mathrm{BE}$ or EAC. Items shown in red and green are upregulated and downregulated in BE, respectively. 
PTEN, which results in an increase in AKT signaling and downstream NF- $\kappa$ B [100]. miR-130b, miR-181b and miR-501-5p are known to drive inflammation through $\mathrm{NF}-\kappa \mathrm{B}$ by targeting the Ubiquitin-Specific-Processing Protease (CYLD), a known NF- $\kappa$ B suppressor [100102]. Mechanistic studies into the role(s) played by these miRNAs in regulating NF- $\kappa \mathrm{B}$ signaling in BE and EAC are needed.

B-Cell CLL/Lymphoma 2 (BCL2) and Cytochrome C Oxidase II (COX2), both downstream NF- $\kappa$ B effectors, are upregulated and associated with apoptotic resistance in BE $[103,104]$. Several BE-related miRNAs which target these genes are upregulated (indicated in Figure 4A with a double asterisk). Upregulation of these miRNAs (shown in Figure 4A) would suppress NF- $\kappa \mathrm{B}$ signaling and is not consistent with the observed increase in NF- $\mathrm{NB}$ signaling $\mathrm{BE}$ or EAC. However, the corresponding miRNA mimics may hold therapeutic potential by increasing apoptosis in BE lesions.

In the transition from $\mathrm{BE}$ to invasive $\mathrm{EAC}$, the Epithelial-Mesenchymal transition (EMT) is a prerequisite for tumor invasion (Figure 4B). EMT, a process by which epithelial cells become migratory and invasive, is regulated by several transcription factors including ZEB1/2 and SNAIL1/2 [105]. The miR-200 family of miRNAs, including miR-200a, miR-200b and miR-200c are known to regulate EMT through inhibiting ZEB1/2, but a role in the $\mathrm{BE}$ to $\mathrm{EAC}$ progression has not been clarified. These miRNAs are upregulated in BE and suppressed in EAC, consistent with a role in promoting EMT during the dysplastic progression to EAC [106, 107].

\section{CONCLUSIONS}

While a number of the key regulators underlying BE pathophysiology and its progression to EAC have been identified, effective protein and miRNA biomarkers for $\mathrm{BE}$ remain poorly defined. As regulators of a third of all human genes, miRNAs have potential beyond clinical biomarkers and may be used to elucidate the interactions among signaling pathways in BE pathogenesis, as well as other human diseases. This review strived to provide mechanistic context by correlating the key regulatory proteins involved in BE with miRNAs that are differentially expressed in BE. Using IPA, we were able to correlate miRNAs dysregulated in $\mathrm{BE}$ to the intestinalization of esophageal tissue through upregulation of Hedgehog signaling, and in the maintenance of epithelial stemness in BE through upregulation of BMP4 signaling. We further elaborated on the potential mechanisms by which dysregulated miRNAs downregulate NOTCH and ERK signaling while upregulating JNK and p38 signaling to induce mucin expression and maintain intestinal identity. We identified miRNAs which potentially play a role in regulating proliferation and tumorigenicity by suppressing WNT signaling in BE and enhancing WNT signaling during the dysplastic progression to EAC. We illustrate how miRNAs which are dysregulated in GERD, $\mathrm{BE}$ and EAC support increased NFkB signaling and expression of pro-inflammatory mediators and apoptotic resistance. Finally, identification of several miRNAs which affect EMT signaling were correlated to the metastatic progression to EAC.

Few studies have compared miRNA signatures from tissue and serum, so it is difficult to predict whether circulating miRNA levels accurately reflect those from esophageal biopsies [108]. Of the $105 \mathrm{BE}-$ related miRNAs discussed in this review, only 13 were characterized from serum or plasma. Additional testing will be required to determine if the remaining miRNAs tested from tissue are part of the circulating miRNA signature of BE. Strong correlations between serum and tissue miRNA levels observed in breast and non-small cell lung cancer signatures is promising, but additional studies are needed in order to determine if BE-related miRNAs identified from tissue samples (Tables 1 and 2) serve as effective circulating biomarkers [109, 110]. Bansal et al. utilized muscle biopsies from BE patients with or without dysplasia to identify dysregulation of miR-15b, miR-21, miR-203, miR-485-5p and let-7a as collectively predictive for dysplasia in BE [26]. Determining whether expression of these miRNAs is similarly altered in serum would provide an initial gauge of how effectively serum miRNA profiles reflect those in $\mathrm{BE}$ lesions.

Transduction of human cancer cells with lentiviral vectors encoding for antisense oligos to selected miRNAs has been shown to reduce pancreatic tumor burden in SCID mice [111]. Accordingly, it is our hope that knockdown of key miRNAs overexpressed in BE (Table 2) may hold therapeutic potential. In particular, knockdown of miR-122-5p, miR-21, miR-200c, miR-7, miR-143, miR-503, mir-424 and miR-181b are of particular interest due to their functional ties to key regulators of $\mathrm{BE}$ progression in the NOTCH, MAPK, EMT, Wnt, NFкB and EMT pathways (Figures 1-4).

While this review focused on the downstream targets of miRNAs known to be dysregulated in BE, it should also be noted that these same miRNAs may be used to predict potential upstream master regulators which mediate BE lesion formation. At least 12 of the $98 \mathrm{BE}-$ related miRNAs are direct targets of $\mathrm{p} 53$, suggesting that p53 may be causal in some fashion. Specifically, miR143, miR-145, miR-191, miR-192, miR-22, miR-25, miR-661 and let-7 are upregulated in BE and validated targets of p53. miR-149, miR-210, miR-32 and miR-378 are downregulated by $\mathrm{p} 53$. A role for $\mathrm{p} 53$ in BE has not been clearly defined, but elevated p53 expression $(>5 \%)$ is associated with progression to advanced neoplasia [112].

Identification of clinically reliable early miRNA biomarkers of $\mathrm{BE}$ will require extensive validation and a deeper understanding of the cellular signaling events which drive BE development. Of the miRNAs discussed in this review, it remains unclear which miRNAs have the 
potential to serve as biomarkers specific to $\mathrm{BE}$ and which are broad spectrum cancer biomarkers. Further studies into the mechanisms by which circulating miRNAs become differentially expressed are needed to identify those miRNAs of real clinical importance. A number of technical challenges remain which have hindered current efforts at identifying miRNA biomarkers including low miRNA yield from serum samples, lack of suitable endogenous miRNA controls, and a lack of strategies to deal with normal variation in circulating miRNA levels. Improved early detection of BE and other cancers will only occur by overcoming these technical challenges and by obtaining a more detailed understanding of miRNA signaling networks.

\section{Abbreviations}

BE: Barrett's esophagus; BMP: bone morphogenic protein; EAC: esophageal adenocarcinoma; EMT: epithelial-to-mesenchymal transition; GERD: gastroesophageal reflux disease; HH: hedgehog; MAPK: map kinase; MDC: metaplasia-dysplasia-carcinoma; miRNA: microRNA; WLE: white light endoscopy.

\section{Author contributions}

RJC and MPC contributed equally. RJC wrote the first draft of the manuscript. MPC collected target information, prepared figures, and edited the manuscript. SA and MK edited the text and revised the manuscript for intellectual content. All authors have read and approved the final version of the manuscript.

\section{ACKNOWLEDGMENTS}

We would like to thank Andrew Stacy for critical reading of the text.

\section{CONFLICTS OF INTEREST} interests.

The authors declare that they have no competing

\section{FUNDING}

This work was supported by a pilot grant from Wright State University and Dayton VA Medical Center (MK and SA).

\section{REFERENCES}

1. Bartel DP. MicroRNAs: genomics, biogenesis, mechanism, and function. Cell. 2004; 116:281-297.

2. Liu H, Kohane IS. Tissue and process specific microRNAmRNA co-expression in mammalian development and malignancy. PLoS One. 2009; 4:e5436.
3. Schwarzenbach H, Nishida N, Calin GA, Pantel K. Clinical relevance of circulating cell-free microRNAs in cancer. Nat Rev Clin Oncol. 2014; 11:145-156.

4. Sharma P. Clinical practice. Barrett's esophagus. N Engl J Med. 2009; 361:2548-2556.

5. El-Serag HB, Sweet S, Winchester CC, Dent J. Update on the epidemiology of gastro-oesophageal reflux disease: a systematic review. Gut. 2014; 63:871-880.

6. Thoguluva Chandrasekar V, Vennalaganti P, Sharma P. Management of Barrett's esophagus: from screening to newer treatments. Rev Gastroenterol Mex. 2016; 81:91-102.

7. Qiao Y, Hyder A, Bae SJ, Zarin W, O’Neill TJ, Marcon NE, Stein L, Thein HH. Surveillance in patients with Barrett's esophagus for early detection of esophageal adenocarcinoma: a systematic review and meta-analysis. Clin Transl Gastroenterol. 2015; 6:e131.

8. Gray NA, Odze RD, Spechler SJ. Buried metaplasia after endoscopic ablation of Barrett's esophagus: a systematic review. Am J Gastroenterol. 2011; 106:1899-1908; quiz 1909.

9. Odze RD. Diagnosis and grading of dysplasia in Barrett's oesophagus. J Clin Pathol. 2006; 59:1029-1038.

10. Roberts KJ, Harper E, Alderson D, Hallissey M. Longterm survival and cost analysis of an annual Barrett's surveillance programme. Eur J Gastroenterol Hepatol. 2010; 22:399-403.

11. Schulmann K, Sterian A, Berki A, Yin J, Sato F, Xu Y, Olaru A, Wang S, Mori Y, Deacu E, Hamilton J, Kan T, Krasna MJ, et al. Inactivation of p16, RUNX3, and HPP1 occurs early in Barrett's-associated neoplastic progression and predicts progression risk. Oncogene. 2005; 24:4138-4148.

12. Groome M, Lindsay J, Ross PE, Cotton JP, Hupp TR, Dillon JF. Use of oesophageal stress response proteins as potential biomarkers in the screening for Barrett's oesophagus. Eur J Gastroenterol Hepatol. 2008; 20:961-965.

13. Goldman A, Chen HD, Roesly HB, Hill KA, Tome ME, Dvorak B, Bernstein H, Dvorak K. Characterization of squamous esophageal cells resistant to bile acids at acidic $\mathrm{pH}$ : implication for Barrett's esophagus pathogenesis. Am J Physiol Gastrointest Liver Physiol. 2011; 300:G292-G302.

14. DiMaio MA, Kwok S, Montgomery KD, Lowe AW, Pai RK. Immunohistochemical panel for distinguishing esophageal adenocarcinoma from squamous cell carcinoma: a combination of p63, cytokeratin 5/6, MUC5AC, and anterior gradient homolog 2 allows optimal subtyping. Hum Pathol. 2012; 43:1799-1807.

15. Bansal A, Fitzgerald RC. Biomarkers in Barrett's esophagus: role in diagnosis, risk stratification, and prediction of response to therapy. Gastroenterol Clin North Am. 2015; 44:373-390.

16. Daniely Y, Liao G, Dixon D, Linnoila RI, Lori A, Randell SH, Oren M, Jetten AM. Critical role of p63 in the development of a normal esophageal and tracheobronchial epithelium. Am J Physiol Cell Physiol. 2004; 287:C171-C181. 
17. Souza RF, Krishnan K, Spechler SJ. Acid, bile, and CDX: the ABCs of making Barrett's metaplasia. Am J Physiol Gastrointest Liver Physiol. 2008; 295:G211-G218.

18. Fassan M, Volinia S, Palatini J, Pizzi M, Baffa R, De Bernard M, Battaglia G, Parente P, Croce CM, Zaninotto G, Ancona E, Rugge M. MicroRNA expression profiling in human Barrett's carcinogenesis. Int J Cancer. 2011; 129:1661-1670.

19. Kan T, Meltzer SJ. MicroRNAs in Barrett's esophagus and esophageal adenocarcinoma. Curr Opin Pharmacol. 2009; 9:727-732.

20. Saad R, Chen Z, Zhu S, Jia P, Zhao Z, Washington MK, Belkhiri A, El-Rifai W. Deciphering the unique MicroRNA signature in human esophageal adenocarcinoma. PLos One. 2013; 8:e64463.

21. Yang H, Gu J, Wang KK, Zhang W, Xing J, Chen Z, Ajani JA, Wu X. MicroRNA expression signatures in Barrett's esophagus and esophageal adenocarcinoma. Clin Cancer Res. 2009; 15:5744-5752.

22. Garman KS, Owzar K, Hauser ER, Westfall K, Anderson BR, Souza RF, Diehl AM, Provenzale D, Shaheen NJ. MicroRNA expression differentiates squamous epithelium from Barrett's esophagus and esophageal cancer. Dig Dis Sci. 2013; 58:3178-3188.

23. Wu X, Ajani JA, Gu J, Chang DW, Tan W, Hildebrandt MA, Huang M, Wang KK, Hawk E. MicroRNA expression signatures during malignant progression from Barrett's esophagus to esophageal adenocarcinoma. Cancer Prev Res. 2013; 6:196-205.

24. Slaby O, Srovnal J, Radova L, Gregar J, Juracek J, Luzna P, Svoboda M, Hajduch M, Ehrmann J. Dynamic changes in microRNA expression profiles reflect progression of Barrett's esophagus to esophageal adenocarcinoma. Carcinogenesis. 2015; 36:521-527.

25. Mallick R, Patnaik SK, Wani S, Bansal A. A systematic review of esophageal MicroRNA markers for diagnosis and monitoring of Barrett's esophagus. Dig Dis Sci. 2016; 61:1039-1050.

26. Bansal A, Lee IH, Hong X, Anand V, Mathur SC, Gaddam S, Rastogi A, Wani SB, Gupta N, Visvanathan M, Sharma P, Christenson LK. Feasibility of mcroRNAs as biomarkers for Barrett's Esophagus progression: a pilot cross-sectional, phase 2 biomarker study. Am J Gastroenterol. 2011; 106:1055-1063.

27. Bus P, Kestens C, Ten Kate FJ, Peters W, Drenth JP, Roodhart JM, Siersema PD, van Baal JW. Profiling of circulating microRNAs in patients with Barrett's esophagus and esophageal adenocarcinoma. J Gastroenterol. 2016; 51:560-570.

28. Bansal A, Gupta V, Wang K. MicroRNA expression signatures during malignant progression from Barrett's esophagus. J Cell Biochem. 2016; 117:1288-1295.

29. Fassan M, Volinia S, Palatini J, Pizzi M, FernandezCymering C, Balistreri M, Realdon S, Battaglia G, Souza R,
Odze RD, Zaninotto G, Croce CM, Rugge MD. MicroRNA expression profiling in the histological subtypes of Barrett's metaplasia. Clin Transl Gastroenterol. 2013; 4:e34.

30. Feber A, Xi L, Luketich JD, Pennathur A, Landreneau RJ, Wu M, Swanson SJ, Godfrey TE, Litle VR. MicroRNA expression profiles of esophageal cancer. J Thorac Cardiovasc Surg. 2008; 135:255-260.

31. Revilla-Nuin B, Parrilla P, Jose Lozano J, Martinez de Haro LF, Ortiz A, Martinez C, Munitiz V, Ruiz de Angulo D, Bermejo J, Molina J, Cayuela ML, Yelamos J. Predictive value of MicroRNAs in the progression of Barrett esophagus to adenocarcinoma in a long-term follow-up study. Ann Surg. 2013; 257:886-893.

32. Wijnhoven BP, Hussey DJ, Watson DI, Tsykin A, Smith CM, Michael MZ, Grp SA. MicroRNA profiling of Barrett's oesophagus and oesophageal adenocarcinoma. Br J Surg. 2010; 97:853-861.

33. Jankowski J. Gene expression in Barrett's mucosa: acute and chronic adaptive responses in the oesophagus. Gut. 1993; 34:1649-1650.

34. Wang X, Ouyang H, Yamamoto Y, Kumar PA, Wei TS, Dagher R, Vincent M, Lu X, Bellizzi AM, Ho KY, Crum CP, Xian W, McKeon F. Residual embryonic cells as precursors of a Barrett's-like metaplasia. Cell. 2011; 145:1023-1035.

35. Yang L, Wang LS, Chen XL, Gatalica Z, Qiu S, Liu Z, Stoner G, Zhang H, Weiss H, Xie J. Hedgehog signaling activation in the development of squamous cell carcinoma and adenocarcinoma of esophagus. Int J Biochem Mol Biol. 2012; 3:46-57.

36. Wang DH, Clemons NJ, Miyashita T, Dupuy AJ, Zhang W, Szczepny A, Corcoran-Schwartz IM, Wilburn DL, Montgomery EA, Wang JS, Jenkins NA, Copeland NA, Harmon JW, et al. Aberrant epithelial-mesenchymal Hedgehog signaling characterizes Barrett's metaplasia. Gastroenterology. 2010; 138:1810-1822.

37. Varjosalo M, Taipale J. Hedgehog: functions and mechanisms. Genes Dev. 2008; 22:2454-2472.

38. Wang X, Zhang Y, Fu Y, Zhang J, Yin L, Pu Y, Liang G. MicroRNA-125b may function as an oncogene in lung cancer cells. Mol Med Rep. 2015; 11:3880-3887.

39. Luo YW, Wang XY, Niu WH, Wang HR, Wen QY, Fan SQ, Zhao R, Li Z, Xiong W, Peng SP, Zeng ZY, Li XL, Li $\mathrm{GY}$, et al. Elevated microRNA-125b levels predict a worse prognosis in HER2-positive breast cancer patients. Oncol Lett. 2017; 13:867-874.

40. Ferretti E, De Smaele E, Miele E, Laneve P, Po A, Pelloni M, Paganelli A, Di Marcotullio L, Caffarelli E, Screpanti I, Bozzoni I, Gulino A. Concerted microRNA control of Hedgehog signalling in cerebellar neuronal progenitor and tumour cells. EMBO J. 2008; 27:2616-2627.

41. Peng Y, Zhang X, Ma Q, Yan R, Qin Y, Zhao Y, Cheng Y, Yang M, Wang Q, Feng X, Huang Y, Huang W, Zhao Z, et al. MiRNA-194 activates the Wnt/beta-catenin signaling pathway in gastric cancer by targeting the negative Wnt regulator, SUFU. Cancer Lett. 2017; 385:117-127. 
42. Lee DY, Deng Z, Wang CH, Yang BB. MicroRNA-378 promotes cell survival, tumor growth, and angiogenesis by targeting SuFu and Fus-1 expression. Proc Natl Acad Sci U S A. 2007; 104:20350-20355.

43. Rishniw M, Rodriguez P, Que J, Burke ZD, Tosh D, Chen H, Chen X. Molecular aspects of esophageal development. Ann N Y Acad Sci. 2011; 1232:309-315.

44. Chen H, Fang Y, Tevebaugh W, Orlando RC, Shaheen NJ, Chen X. Molecular mechanisms of Barrett's esophagus. Dig Dis Sci. 2011; 56:3405-3420.

45. Wang RN, Green J, Wang Z, Deng Y, Qiao M, Peabody M, Zhang Q, Ye J, Yan Z, Denduluri S, Idowu O, Li M, Shen C, et al. Bone Morphogenetic Protein (BMP) signaling in development and human diseases. Genes Dis. 2014; 1:87-105.

46. Wang DH, Tiwari A, Kim ME, Clemons NJ, Regmi NL, Hodges WA, Berman DM, Montgomery EA, Watkins DN, Zhang X, Zhang Q, Jie C, Spechler SJ, et al. Hedgehog signaling regulates FOXA2 in esophageal embryogenesis and Barrett's metaplasia. J Clin Invest. 2014; 124:3767-3780.

47. Clemons NJ, Wang DH, Croagh D, Tikoo A, Fennell CM, Murone C, Scott AM, Watkins DN, Phillips WA. Sox9 drives columnar differentiation of esophageal squamous epithelium: a possible role in the pathogenesis of Barrett's esophagus. Am J Physiol Gastrointest Liver Physiol. 2012; 303:G1335-G1346.

48. Cao HJ, Jheon A, Li X, Sun Z, Wang JB, Florez S, Zhang ZC, McManus MT, Klein OD, Amendt BA. The Pitx2:miR200c/141: noggin pathway regulates Bmp signaling and ameloblast differentiation. Development. 2013; 140:3348-3359.

49. Emmrich S, Rasche M, Schoning J, Reimer C, Keihani S, Maroz A, Xie Y, Li Z, Schambach A, Reinhardt D, Klusmann JH. miR-99a/100 125b tricistrons regulate hematopoietic stem and progenitor cell homeostasis by shifting the balance between TGFbeta and Wnt signaling. Genes Dev. 2014; 28:858-874.

50. Tamagawa $\mathrm{Y}$, Ishimura N, Uno G, Yuki T, Kazumori H, Ishihara S, Amano Y, Kinoshita Y. Notch signaling pathway and $\mathrm{Cdx} 2$ expression in the development of Barrett's esophagus. Lab Invest. 2012; 92:896-909.

51. Yamamoto S, Schulze KL, Bellen HJ. Introduction to Notch signaling. Methods Mol Biol. 2014; 1187:1-14.

52. Vega ME, Giroux V, Natsuizaka M, Liu M, Klein-Szanto AJ, Stairs DB, Nakagawa H, Wang KK, Wang TC, Lynch JP, Rustgi AK. Inhibition of Notch signaling enhances transdifferentiation of the esophageal squamous epithelium towards a Barrett's-like metaplasia via KLF4. Cell Cycle. 2014; 13:3857-3866.

53. Wang Z, Chen J, Capobianco AJ. The Notch signaling pathway in esophageal adenocarcinoma. Cell Mol Biol. $2015 ; 61: 24-32$.
54. Vallejo DM, Caparros E, Dominguez M. Targeting Notch signalling by the conserved miR-8/200 microRNA family in development and cancer cells. EMBO J. 2011; 30:756-769.

55. Hashimi ST, Fulcher JA, Chang MH, Gov L, Wang S, Lee B. MicroRNA profiling identifies miR-34a and miR-21 and their target genes JAG1 and WNT1 in the coordinate regulation of dendritic cell differentiation. Blood. 2009; 114:404-414.

56. Coglievina M, Guarnaccia C, Zlatev V, Pongor S, Pintar A. Jagged-1 juxtamembrane region: biochemical characterization and cleavage by ADAM17 (TACE) catalytic domain. Biochem Biophys Res Commun. 2013; 432:666-671.

57. Tsai WC, Hsu PW, Lai TC, Chau GY, Lin CW, Chen CM, Lin CD, Liao YL, Wang JL, Chau YP, Hsu MT, Hsiao M, Huang HD, et al. MicroRNA-122, a tumor suppressor microRNA that regulates intrahepatic metastasis of hepatocellular carcinoma. Hepatology. 2009; 49:1571-1582.

58. Hung PS, Liu CJ, Chou CS, Kao SY, Yang CC, Chang KW, Chiu TH, Lin SC. miR-146a enhances the oncogenicity of oral carcinoma by concomitant targeting of the IRAK1, TRAF6 and NUMB genes. PLoS One. 2013; 8:e79926.

59. Zavadil J, Ye H, Liu Z, Wu J, Lee P, Hernando E, Soteropoulos P, Toruner GA, Wei JJ. Profiling and functional analyses of microRNAs and their target gene products in human uterine leiomyomas. PLoS One. 2010; 5:e12362.

60. Phillips RW, Frierson HF Jr, Moskaluk CA. Cdx2 as a marker of epithelial intestinal differentiation in the esophagus. Am J Surg Pathol. 2003; 27:1442-1447.

61. Souza RF, Shewmake K, Terada LS, Spechler SJ. Acid exposure activates the mitogen-activated protein kinase pathways in Barrett's esophagus. Gastroenterology. 2002; 122:299-307.

62. Houde M, Laprise P, Jean D, Blais M, Asselin C, Rivard N. Intestinal epithelial cell differentiation involves activation of p38 mitogen-activated protein kinase that regulates the homeobox transcription factor CDX2. J Biol Chem. 2001; 276:21885-21894.

63. Burnat G, Rau T, Elshimi E, Hahn EG, Konturek PC. Bile acids induce overexpression of homeobox gene CDX-2 and vascular endothelial growth factor (VEGF) in human Barrett's esophageal mucosa and adenocarcinoma cell line. Scand J Gastroenterol. 2007; 42:1460-1465.

64. van Baal JW, Diks SH, Wanders RJ, Rygiel AM, Milano F, Joore J, Bergman JJ, Peppelenbosch MP, Krishnadath KK. Comparison of kinome profiles of Barrett's esophagus with normal squamous esophagus and normal gastric cardia. Cancer Res. 2006; 66:11605-11612.

65. Zhang HY, Zhang X, Chen X, Thomas D, Hormi-Carver $\mathrm{K}$, Elder F, Spechler SJ, Souza RF. Differences in activity and phosphorylation of MAPK enzymes in esophageal squamous cells of GERD patients with and without Barrett's 
esophagus. Am J Physiol Gastrointest Liver Physiol. 2008; 295:G470-G478.

66. Lemieux E, Boucher MJ, Mongrain S, Boudreau F, Asselin C, Rivard N. Constitutive activation of the MEK/ERK pathway inhibits intestinal epithelial cell differentiation. Am J Physiol Gastrointest Liver Physiol. 2011; 301:G719-G730.

67. Xie J, Chen M, Zhou J, Mo MS, Zhu LH, Liu YP, Gui QJ, Zhang L, Li GQ. miR-7 inhibits the invasion and metastasis of gastric cancer cells by suppressing epidermal growth factor receptor expression. Oncol Rep. 2014; 31:1715-1722.

68. Kim J, Kang Y, Kojima Y, Lighthouse JK, Hu X, Aldred MA, McLean DL, Park H, Comhair SA, Greif DM, Erzurum SC, Chun HJ. An endothelial apelin-FGF link mediated by miR-424 and miR-503 is disrupted in pulmonary arterial hypertension. Nat Med. 2013; 19:74-82.

69. Yu Z, Ye S, Hu G, Lv M, Tu Z, Zhou K, Li Q. The RAFMEK-ERK pathway: targeting ERK to overcome obstacles to effective cancer therapy. Future Med Chem. 2015; 7:269-289.

70. Pekow J, Meckel K, Dougherty U, Butun F, Mustafi R, Lim J, Crofton C, Chen X, Joseph L, Bissonnette M. Tumor suppressors miR-143 and miR-145 and predicted target proteins API5, ERK5, K-RAS, and IRS-1 are differentially expressed in proximal and distal colon. Am J Physiol Gastrointest Liver Physiol. 2015; 308:G179-G187.

71. Liu Z, Liu Y, Li L, Xu Z, Bi B, Wang Y, Li JY. MiR-7-5p is frequently downregulated in glioblastoma microvasculature and inhibits vascular endothelial cell proliferation by targeting RAF1. Tumour Biol. 2014; 35:10177-10184.

72. Whitmarsh AJ, Davis RJ. Transcription factor AP-1 regulation by mitogen-activated protein kinase signal transduction pathways. J Mol Med. 1996; 74:589-607.

73. Song S, Byrd JC, Guha S, Liu KF, Koul D, Bresalier RS. Induction of MUC5AC mucin by conjugated bile acids in the esophagus involves the phosphatidylinositol 3-kinase/ protein kinase C/activator protein-1 pathway. Cancer. 2011; 117:2386-2397.

74. Song S, Guha S, Liu K, Buttar NS, Bresalier RS. COX-2 induction by unconjugated bile acids involves reactive oxygen species-mediated signalling pathways in Barrett's oesophagus and oesophageal adenocarcinoma. Gut. 2007; 56:1512-1521.

75. Looby E, Abdel-Latif MM, Athie-Morales V, Duggan S, Long A, Kelleher D. Deoxycholate induces COX-2 expression via Erk1/2-, p38-MAPK, AP-1-dependent mechanisms in esophageal cancer cells. BMC Cancer. 2009; 9:190.

76. Kappelmann M, Kuphal S, Meister G, Vardimon L, Bosserhoff AK. MicroRNA miR-125b controls melanoma progression by direct regulation of c-Jun protein expression. Oncogene. 2013; 32:2984-2991.
77. Pinto D, Gregorieff A, Begthel H, Clevers H. Canonical Wnt signals are essential for homeostasis of the intestinal epithelium. Genes Dev. 2003; 17:1709-1713.

78. Moyes LH, McEwan H, Radulescu S, Pawlikowski J, Lamm CG, Nixon C, Sansom OJ, Going JJ, Fullarton GM, Adams PD. Activation of Wnt signalling promotes development of dysplasia in Barrett's oesophagus. J Pathol. 2012; 228:99-112.

79. Lyros O, Rafiee P, Nie L, Medda R, Jovanovic N, Otterson MF, Behmaram B, Gockel I, Mackinnon A, Shaker R. Wnt/ $\beta$-catenin signaling activation beyond robust nuclear $\beta$-catenin accumulation in nondysplastic Barrett's esophagus: regulation via Dickkopf-1()(). Neoplasia. 2015; 17:598-611.

80. Clement G, Jablons DM, Benhattar J. Targeting the Wnt signaling pathway to treat Barrett's esophagus. Expert Opin Ther Targets. 2007; 11:375-389.

81. Clement G, Braunschweig R, Pasquier N, Bosman FT, Benhattar J. Alterations of the Wnt signaling pathway during the neoplastic progression of Barrett's esophagus. Oncogene. 2006; 25:3084-3092.

82. Jia Y, Yang Y, Zhan Q, Brock MV, Zheng X, Yu Y, Herman JG, Guo M. Inhibition of SOX17 by microRNA 141 and methylation activates the WNT signaling pathway in esophageal cancer. J Mol Diagn. 2012; 14:577-585.

83. Leidner RS, Ravi L, Leahy P, Chen Y, Bednarchik B, Streppel M, Canto M, Wang JS, Maitra A, Willis J, Markowitz SD, Barnholtz-Sloan J, Adams MD, et al. The microRNAs, MiR-31 and MiR-375, as candidate markers in Barrett's esophageal carcinogenesis. Genes Chromosomes Cancer. 2012; 51:473-479.

84. Xi S, Yang M, Tao Y, Xu H, Shan J, Inchauste S, Zhang M, Mercedes L, Hong JA, Rao M, Schrump DS. Cigarette smoke induces C/EBP-beta-mediated activation of miR-31 in normal human respiratory epithelia and lung cancer cells. PLoS One. 2010; 5:e13764.

85. Zhou W, Li Y, Gou S, Xiong J, Wu H, Wang C, Yan H, Liu T. MiR-744 increases tumorigenicity of pancreatic cancer by activating Wnt/beta-catenin pathway. Oncotarget. 2015; 6:37557-37569. https://doi.org/10.18632/oncotarget.5317.

86. Ji J, Yamashita T, Budhu A, Forgues M, Jia HL, Li C, Deng C, Wauthier E, Reid LM, Ye QH, Qin LX, Yang W, Wang HY, et al. Identification of microRNA-181 by genome-wide screening as a critical player in EpCAM-positive hepatic cancer stem cells. Hepatology. 2009; 50:472-480.

87. Wang X, Chen X, Meng Q, Jing H, Lu H, Yang Y, Cai L, Zhao Y. MiR-181b regulates cisplatin chemosensitivity and metastasis by targeting TGFbetaR1/Smad signaling pathway in NSCLC. Sci Rep. 2015; 5:17618.

88. Zheng Y, Lv X, Wang X, Wang B, Shao X, Huang Y, Shi L, Chen Z, Huang J, Huang P. MiR-181b promotes chemoresistance in breast cancer by regulating Bim expression. Oncol Rep. 2016; 35:683-690. 
89. Fan D, Ren B, Yang X, Liu J, Zhang Z. Upregulation of miR-501-5p activates the wnt/beta-catenin signaling pathway and enhances stem cell-like phenotype in gastric cancer. J Exp Clin Cancer Res. 2016; 35:177.

90. Saydam O, Shen Y, Wurdinger T, Senol O, Boke E, James MF, Tannous BA, Stemmer-Rachamimov AO, Yi M, Stephens RM, Fraefel C, Gusella JF, Krichevsky AM, Breakefield XO. Downregulated microRNA-200a in meningiomas promotes tumor growth by reducing E-cadherin and activating the $\mathrm{Wnt} /$ beta-catenin signaling pathway. Mol Cell Biol. 2009; 29:5923-5940.

91. Zhao H, Wang J, Gao L, Wang R, Liu X, Gao Z, Tao $\mathrm{Z}, \mathrm{Xu} \mathrm{C}$, Song J, Ji X, Luo Y. MiRNA-424 protects against permanent focal cerebral ischemia injury in mice involving suppressing microglia activation. Stroke. 2013; 44:1706-1713.

92. Xu YY, Wu HJ, Ma HD, Xu LP, Huo Y, Yin LR. MicroRNA-503 suppresses proliferation and cellcycle progression of endometrioid endometrial cancer by negatively regulating cyclin D1. FEBS J. 2013; 280:3768-3779.

93. Sachdeva M, Mo YY. miR-145-mediated suppression of cell growth, invasion and metastasis. Am J Transl Res. 2010; 2:170-180.

94. Nadiminty N, Tummala R, Lou W, Zhu Y, Zhang J, Chen $\mathrm{X}$, deVere White RW, Kung HJ, Evans CP, Gao AC. MicroRNA let-7c suppresses androgen receptor expression and activity via regulation of Myc expression in prostate cancer cells. J Biol Chem. 2012; 287:1527-1537.

95. O'Riordan JM, Abdel-latif MM, Ravi N, McNamara D, Byrne PJ, McDonald GS, Keeling PW, Kelleher D, Reynolds JV. Proinflammatory cytokine and nuclear factor kappa-B expression along the inflammation-metaplasiadysplasia-adenocarcinoma sequence in the esophagus. Am J Gastroenterol. 2005; 100:1257-1264.

96. McAdam E, Haboubi HN, Griffiths AP, Baxter JN, SpencerHarty S, Davies C, Jenkins GJ. Reflux composition influences the level of NF-kappaB activation and upstream kinase preference in oesophageal adenocarcinoma cells. Int J Cancer. 2015; 136:527-535.

97. Abdel-Latif MM, O'Riordan J, Windle HJ, Carton E, Ravi N, Kelleher D, Reynolds JV. NF-kappaB activation in esophageal adenocarcinoma: relationship to Barrett's metaplasia, survival, and response to neoadjuvant chemoradiotherapy. Ann Surg. 2004; 239:491-500.

98. Jenkins GJ, Harries K, Doak SH, Wilmes A, Griffiths AP, Baxter JN, Parry JM. The bile acid deoxycholic acid (DCA) at neutral $\mathrm{pH}$ activates NF-kappaB and induces IL-8 expression in oesophageal cells in vitro. Carcinogenesis. 2004; 25:317-323.

99. Taddei A, Fabbroni V, Pini A, Lucarini L, Ringressi MN, Fantappie O, Bani D, Messerini L, Masini E, Bechi P. Cyclooxygenase-2 and inflammation mediators have a crucial role in reflux-related esophageal histological changes and Barrett's esophagus. Dig Dis Sci. 2014; 59:949-957.

100. Ma X, Becker Buscaglia LE, Barker JR, Li Y. MicroRNAs in NF-kappaB signaling. J Mol Cell Biol. 2011; 3:159-166.

101. Wang Y, Mao G, Lv Y, Huang Q, Wang G. MicroRNA$181 \mathrm{~b}$ stimulates inflammation via the nuclear factor-kappaB signaling pathway. Exp Ther Med. 2015; 10:1584-1590.

102. Iliopoulos D, Jaeger SA, Hirsch HA, Bulyk ML, Struhl K. STAT3 activation of miR-21 and miR-181b-1 via PTEN, CYLD are part of the epigenetic switch linking inflammation to cancer. Mol Cell. 2010; 39:493-506.

103. Hormi-Carver K, Zhang X, Zhang HY, Whitehead RH, Terada LS, Spechler SJ, Souza RF. Unlike esophageal squamous cells, Barrett's epithelial cells resist apoptosis by activating the nuclear factor-kappaB pathway. Cancer Res. 2009; 69:672-677.

104. Mobius C, Stein HJ, Spiess C, Becker I, Feith M, Theisen J, Gais P, Jutting U, Siewert JR. COX2 expression, angiogenesis, proliferation and survival in Barrett's cancer. Eur J Surg Oncol. 2005; 31:755-759.

105. Lamouille S, Xu J, Derynck R. Molecular mechanisms of epithelial-mesenchymal transition. Nat Rev Mol Cell Biol. 2014; 15:178-196.

106. Gregory PA, Bert AG, Paterson EL, Barry SC, Tsykin A, Farshid G, Vadas MA, Khew-Goodall Y, Goodall GJ. The miR-200 family and miR-205 regulate epithelial to mesenchymal transition by targeting ZEB1 and SIP1. Nat Cell Biol. 2008; 10:593-601.

107. Smith CM, Watson DI, Leong MP, Mayne GC, Michael MZ, Wijnhoven BP, Hussey DJ. miR-200 family expression is downregulated upon neoplastic progression of Barrett's esophagus. World J Gastroenterol. 2011; 17:1036-1044.

108. Bansal A, Hong X, Lee IH, Krishnadath KK, Mathur SC, Gunewardena S, Rastogi A, Sharma P, Christenson LK. MicroRNA expression can be a promising strategy for the detection of Barrett's esophagus: a pilot study. Clin Transl Gastroenterol. 2014; 5:e65.

109. Guo J, Meng R, Yin Z, Li P, Zhou R, Zhang S, Dong X, Liu $\mathrm{L}, \mathrm{Wu} \mathrm{G}$. A serum microRNA signature as a prognostic factor for patients with advanced NSCLC and its association with tissue microRNA expression profiles. Mol Med Rep. $2016 ; 13: 4643-4653$.

110. Al-Khanbashi M, Caramuta S, Alajmi AM, Al-Haddabi I, Al-Riyami M, Lui WO, Al-Moundhri MS. Tissue and Serum miRNA profile in locally advanced breast cancer (LABC) in response to neo-adjuvant chemotherapy (NAC) treatment. PLoS One. 2016; 11:e0152032.

111. Sicard F, Gayral M, Lulka H, Buscail L, Cordelier P. Targeting miR-21 for the therapy of pancreatic cancer. Mol Ther. 2013; 21:986-994.

112. Horvath B, Singh P, Xie H, Thota PN, Sun X, Liu X. Expression of $\mathrm{p} 53$ predicts risk of prevalent and incident advanced neoplasia in patients with Barrett's esophagus and 
epithelial changes indefinite for dysplasia. Gastroenterol Rep. 2016; 4:304-309.

113. Bansal A, Lee IH, Hong X, Mathur SC, Tawfik O, Rastogi A, Buttar N, Visvanathan M, Sharma P, Christenson LK. Discovery and validation of Barrett's esophagus microRNA transcriptome by next generation sequencing. PLoS One. 2013; 8:e54240.
114. Sreedharan L, Mayne GC, Watson DI, Bright T, Lord RV, Ansar A, Wang T, Kist J, Astill DS, Hussey DJ. MicroRNA profile in neosquamous esophageal mucosa following ablation of Barrett's esophagus. World J Gastroenterol. 2017; 23:5508-5518. 